\title{
The role of dry land forests for climate change adaptation: the case of Liben Woreda, Southern Oromia, Ethiopia
}

\author{
Wondimagegn Amanuel $^{1 *}$ (D, Musse Tesfaye ${ }^{1}$, Adefires Worku², Gezahegne Seyoum ${ }^{1}$ and Zenebe Mekonnen ${ }^{2}$
}

\begin{abstract}
Background: Despite the increasing role of dry forests in climate change adaptation and mitigation, these versatile resources has got less attention in the national and regional planning, their potential to enhance the local and national economy has been overlooked, and their contribution to sustainable environmental management has not been recognized. Hence, the objective of this study was to assess the socioeconomic contribution of dry forests and forest products to climate change adaptation in the Liben Woreda, Southern Oromia region of Ethiopia.

Methods: For this study, an integrated qualitative and quantitative approach was used. A total of 74 households from villages in the Bulbul, Boba, and Melka-Guba kebeles were randomly selected for the household survey.

Results: Results showed that $75 \%$ of the respondents in the area indicated that climate change has become their major sources of vulnerability, where drought has been manifested in the form of crops failure and massive death of livestock particularly cattle species. The main income strategies of the study households include livestock, crop, forests such as gum and resins, firewood and charcoal and non-farm activities such as in the form of petty trade, wage and aid. The average total household income was ETB 11,209.7. Out of this, dry forest income constituted 15\% of the total income. In addition to using dry forests as rangeland for livestock, the communities collect wood for construction, fodder, traditional medicine, and forest food both for subsistence and for sale. On the other hand, dry forest products could be considered as less vulnerable, rather resilient livelihood strategies to climate- and environment-related risks compared to livestock and crop production such as in the face of drought periods. More than $48.6 \%$ of the households argued that the income generated from dry forests increased substantially due to increment in the level of engagement of family members in forest based income activities. On the other hand, $35.8 \%$ of the households responded that livestock production, particularly camels and goats, have been making the livelihood strategies of the respondents more resilient indicating the shift made from grazers browsers to livestock. In general trends show that, the trends of livelihood dependency on dry forest were highly increasing indicating the importance of dry forest income in responsse to frequent droughts.
\end{abstract}

Conclusions: Dry forest income has been becoming crucial livelihood staretgy in response to frequent droughts in the study area and hence, it is important to improve the management of dry forests for livelihood enhancement, while also securing their long-term ecological functions.

Keywords: Drought, Dry forests, Livelihood strategies, Vulnerability

\footnotetext{
* Correspondence: wondimagegn.amanuel@yahoo.com

${ }^{1}$ Hawassa Environment and Forest Research Center, P.O.Box: 1832, Hawassa,

Ethiopia

Full list of author information is available at the end of the article
}

(c) The Author(s). 2019 Open Access This article is distributed under the terms of the Creative Commons Attribution 4.0 International License (http://creativecommons.org/licenses/by/4.0/), which permits unrestricted use, distribution, and reproduction in any medium, provided you give appropriate credit to the original author(s) and the source, provide a link to the Creative Commons license, and indicate if changes were made. The Creative Commons Public Domain Dedication waiver (http://creativecommons.org/publicdomain/zero/1.0/) applies to the data made available in this article, unless otherwise stated. 


\section{Background}

The vast majority (over 70\%) of the landmass of Ethiopia is dryland, characterized by low and unpredictable rainfall patterns (ECA 2007). These regions are poorly developed and suffer historical, political, and economic marginalization (Fekadu 2009). Traditional pastoralism and agropastoralism are the major livelihood strategies in the drylands, where households depend on livestock production for a significant proportion of their food, income, and traction power (FAO 2009). Pastoralism and agropastoralism employ an estimated $14 \%$ of the human and $40 \%$ of the livestock population in Ethiopia. Pastoral areas cover some $60 \%$ of the total land area in Ethiopia, and the country stands fifth in the world in its pastoral and agropastoral population size (Bekele and Amsalu 2012).

Despite the long-standing adaptation practices, recent trends indicate an increase in drought incidence in the dry land eco-regions in the Horn of Africa in general and in Ethiopia in particular (IPCC 2007; NAPA 2007). Increasing in frequency and intensity of drought leads to a rise in the vulnerability of pastoral and agropastoral communities (Homann 2008) as these communities are continuously losing a significant proportion of their livestock assets (Kassahun et al. 2008).

A continued severe environmental degradation, shrinking resource bases, and pastoralist mobility routes are becoming major problems facing these production systems (Fekadu 2010, 2013). A post-drought livestock re-stocking, a common phenomenon in the drylands, has become a difficult process due to protracted drought, alarming rangeland degradation, and diseases (Homann 2008). The gradual depletion of livestock assets, exacerbated by existing limited alternative coping strategies, is therefore putting additional pressure on livelihood systems. According to Fekadu (2013), increase in the frequency of violence, political insecurity, and a decline in the capacity of customary authority in conflict management, on the one hand, and the lack of enforcement of formal institutional framework, on the other hand, gradually exacerbated the vulnerability of these communities.

According to Davies et al. (2012), such complex socioecological problems facing the pastoral and agropastoral livelihoods call for informed policy interventions to achieve solutions to environmental- and livelihood-related challenges. The increasingly uncertain climatic conditions and related impacts across the drylands demand for new and integrated resource management approaches that facilitate more resilient land-use planning (IPCC 2007). Promotion of sustainable forest management is a key strategy put forth in recent international and national negotiations to reduce the negative impacts of climate (CIFOR 2005).

According to FAO (2010), the role of forests in climate change adaptation and mitigation is important; the sustained provision of ecosystem goods and services can help people adapt to the local consequences of a changing climate, while the carbon stored in these ecosystems, if well managed, can contribute to climate change mitigation (Robledo et al. 2012). According to FAO (2010), the role of forests and woodlands is even more important, both biologically and socioeconomically, in arid lands than it is elsewhere, where rangelands, agroforestry parklands, and trees outside forests play vital roles in the livelihood of communities in Africa's drylands.

Forestry managers and professionals recommend integration and responsible management of the currently marginalized dry forests in Africa (FAO 2010; Lemenih and Kassa 2011). There are various socioeconomic, ecological, and political reasons for Ethiopia to sustainably manage its dry forests. For instance, value-added commercialization of gums and resins produced from dry forests would offer access to additional income for the drought-prone pastoral and agropastoral households and the national and regional economy at large (Lemenih and Kassa 2011; Worku et al. 2011). Demonstrating the ways through which dry forests contribute to increasing income and reducing poverty would lend additional weight and relevance to forest management initiatives that also contribute in combating desertification (FAO 2010; Lemenih and Kassa 2011).

However, despite their values, dry forests are caught in a spiral of deforestation, fragmentation, and degradation (FAO 2010). Until recently, dry forests in Ethiopia and elsewhere in the Horn have had less attention in the national as well as regional planning, their potential to enhance the local and national economy has been overlooked, and their contribution to sustainable environmental management has not been recognized (FAO 2010; Lemenih and Kassa 2011; Worku et al. 2011). Therefore, this study assessed the socioeconomic contribution of dry forests and forest products to climate change adaptation in Liben Woreda of Guji zone, Southern Oromia regional state of Ethiopia. Hence, the specific research questions to be addressed in this study are as follows: (1) How does the dry forest ecosystem contribute to household total income? (2) What are factors that influence households' total annual income and dry forest annual income? (3) How does dry forest ecosystem play role as a coping strategy and adaptation to the climate extremes?

\section{Methods}

\section{Description of study area}

The study was conducted in Liben Woreda of Guji zone, situated in the Oromia Regional State of Ethiopia. It is located at about $630 \mathrm{~km}$ south of Addis Ababa. Geographically, it is situated between $5^{\circ} 5^{\prime} 10^{\prime \prime}$ to $5^{\circ} 7^{\prime} 50^{\prime \prime}$ North and $39^{\circ} 32^{\prime} 30^{\prime \prime}$ to $39^{\circ} 36^{\prime} 30^{\prime \prime}$ East (Fig. 1). Except for the central mountain range and scattered volcanic cones and craters, the landscape is dominantly a gentle elevation between 1000 and 1600 m.a.s.l (Coppock 1994). Agroecologically, 


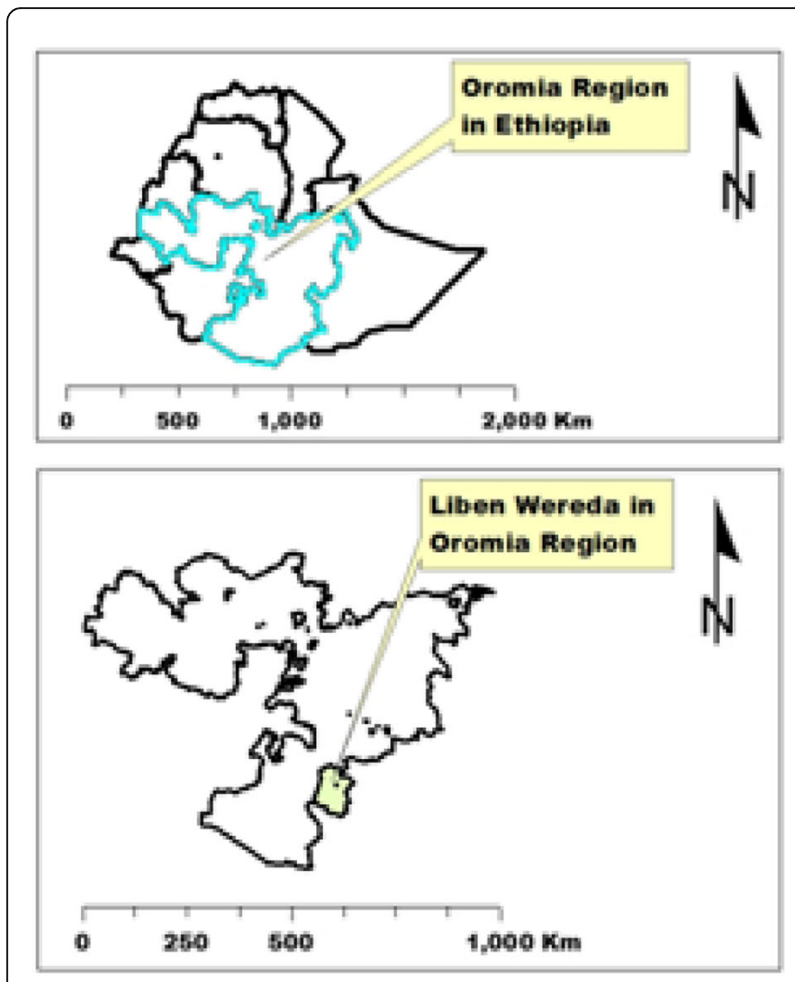

Fig. 1 Geographic location of study area under map of Ethiopia

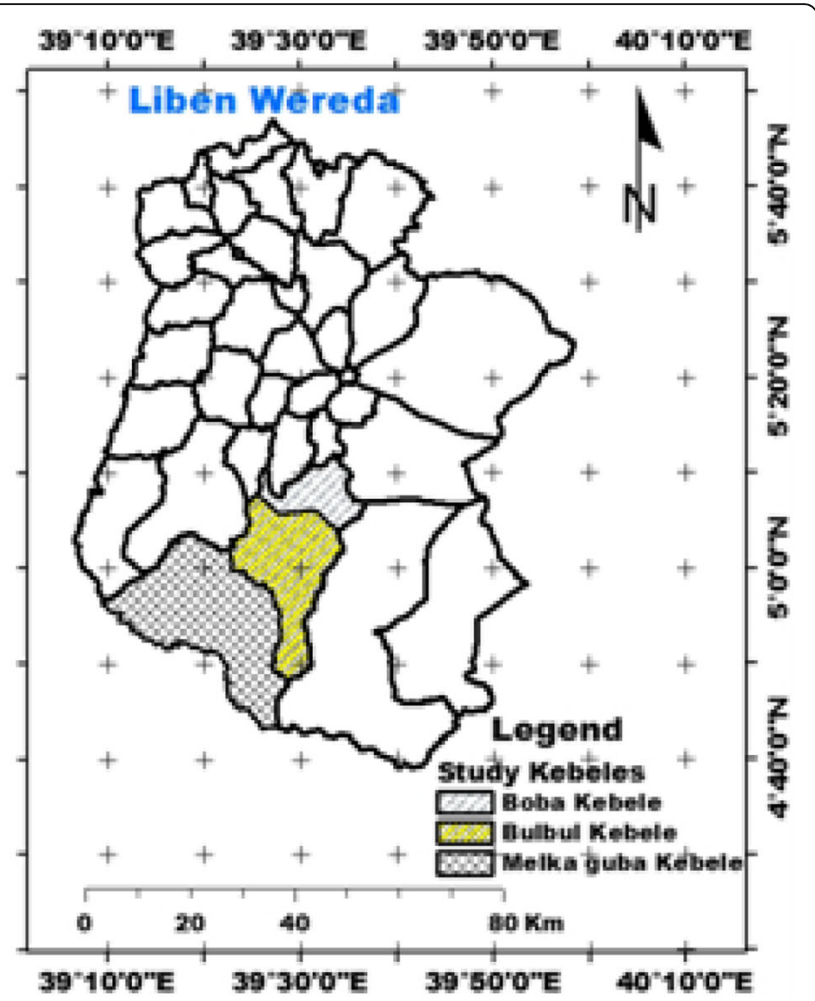

the Liben district is categorized under "dry kola." The mean monthly minimum and maximum temperature is $16^{\circ} \mathrm{C}$ and $28^{\circ} \mathrm{C}$, respectively. The rainfall pattern is bimodal, and total annual rainfall ranges from 460 to $790 \mathrm{~mm}$ with an average of $609 \mathrm{~mm}$. The main rainy season in the district occurs from February to June that accounts for about 55\% and a minor rainy season from September to December that accounts for 41\% (Coppock 1994). Based on the 2007 census conducted by the Central Statistical Agency (CSA 2007), this district has a total population of 79,981, of whom 38,284 are men and 41,697 women; 2198 or $2.75 \%$ of its population are urban dwellers with an annual population growth rate of $2.7 \%$ and a population density of approximately 280 persons per square kilometer. On the other hand, woodlands of the region rangelands are mainly characterized as Combretum-Terminalia-dominated woodland (Haugen 1992). Besides, species of the genera Combretum, Terminalia, Acacia, Pistacia, Commiphora, Lannea, Euclea, and Olea are common in the studied area.

\section{Research methodology \\ Sampling methods}

Random sampling was employed to select study villages and respondents. Three administrative kebeles, i.e., Melka-Guba, Bulbul, and Boba, out of five kebeles were selected based on their accessibility, dry forest dependency of the community, and relative availability of prior studies on dry forests. Liben Woreda is mainly characterized by agropastoral livelihoods, followed by pastoral. Two villages from each kebeles were randomly selected. A total of 74 households (i.e., 30 households from villages in the Bulbul kebele, 24 households from villages in the Boba kebele, and 20 households from villages in the Melka-Guba kebele, covering 5 to $25 \%$ of village residents) were randomly selected for a household survey. In addition, 30 individuals participated in a focus group discussion, and 15 key informants (10 and 5 from each kebele) were purposely selected for an in-depth case study and interviews. Population sampling followed procedures described in Campbell et al. (2002) and Zenteno et al. (2012).

\section{Research design}

A reconnaissance field survey was made to obtain an overview of the study site, followed by a detailed preliminary survey, which was made between the fourth week of January to the end of February 2017. Guided by principles of social-ecological co-evolution theory (Colding et al. 2003), mixed quantitative and qualitative research design (Creswell 2009) was employed to collect data.

\section{Data collection}

For this study, an integrated qualitative and quantitative approach method was used. The primary data were collected through household surveys, focus group discussions, key 
informant interviews, and a guided transect walk for observation (Campbell et al. 2002; Cavendish 2003). Data from household heads was collected based on a detailed questionnaire formulated in line with the prototype developed by the Poverty Environment Network (PEN) (CIFOR 2010). A structured questionnaire that includes both closed- and open-ended questions was designed and employed to generate quantitative and qualitative data from the respondents. The main secondary data sources that were used in this research were both hard copies and online materials such as published and unpublished articles, proceedings, project reports, and other data available at district, zonal, regional, national, and international levels. Three local enumerators who can understand English and "Afan Oromo" language were hired and trained on how to administer the questionnaire. Pre-testing of the questionnaire was conducted to see about its inclusiveness, validity, relevance, and comprehensiveness. Based on the pre-testing feedback, the final questionnaire was prepared and administered accordingly. Data were collected on a number of variables including household characteristics, livelihood strategies, household asset and income composition, expenditure, preference of dry forest management system, dry forest products collected, push and pull factors conditioning dry forest income dependence, drought trend and the consequent vulnerability, and ex-ante risk and ex-post coping and adaptation strategies of dry forests.

\section{Data analysis}

The Statistical Package for Social Scientists (SPSS) version 20.0 software was employed to analyze the data drawn from the household survey. Descriptive statistics like mean, percentage, and frequency distribution were used to analyze quantitative data. Then, the analyzed data was summarized and organized in tables and figures. Qualitative data generated from key informant interview, focus group discussion, and secondary sources was analyzed by narrative description and interpreted on spot. On the other hand, the multinomial logit model (MLM) is one of the econometric models which mainly helps to analyze the dependent variables which are categorical with the other independent variables which are either categorical or continuous. This model was used to analyze factors which influence the immediate action and coping capacity of sample households for climate extreme events. Moreover, univariate analysis of variance was done to analyze factors of mean total annual income and mean total forest income in the study area.

\section{Results}

\section{Demographic characteristics of sampled households}

The structured questionnaire was administrated to a total of 74 household heads. Of this, the sociodemographic information showed that majorities of the sampled households (75.7\%) were male-headed, while the rest were female-headed (Table 1). This shows that male-headed households highly dominated the female-headed households in the surveyed area. On the other hand, the mean respondents' age was 44 with a minimum and maximum of 22 and 74, respectively (Table 1). Regarding the level of literacy, the results showed that there is still a low penetration of formal education system. Only $3 \%$ of the studied community completed the secondary level of education, and more than half $(66.2 \%)$ of the interviewed household did not follow formal education to write and read. Others, constituting $22 \%$, have got access to attend primary level of education (Table 1). Although the educational background of household heads is believed to be an important feature that determines the readiness of households to choose adaptation strategies to climate change and variability through accepting new ideas and innovations, the survey result showed majority of the households who did not attend formal education perceived climate change and respond to adapt to the change.

On the other side, $95.9 \%$ of the interviewed household heads were married. The mean family size of the surveyed households was 6.95 with a minimum and maximum of 2 and 13, respectively. As results showed, the majority of surveyed households $(87.8 \%)$ were under the agropastoralist category who manage their land as a rangeland for the use of livestock pasture and the rest few interviewed household heads $(6.8 \%)$ indicated that they were engaged with cultivation on their private farmlands for income diversification from crop production despite the partial pastoral mode of livelihoods (Table 1). The mean land holding size of the household was 3.95 with a maximum of 15.0 ha of land. The mean livestock holding of the surveyed households was about 10.21 $\mathrm{TLU}^{1}$ (tropical livestock unit) with a maximum of

Table 1 Socioeconomic characteristics of the sampled households

\begin{tabular}{ll}
\hline Socioeconomic characteristics & Descriptions \\
\hline Gender & Male $75.7 \%$ and female 24.3\% \\
Age & Mean 44 and range 22-74 \\
Literacy level & Illiterate 66.2\%, primary 22\%, and \\
& secondary 3\% \\
Family size & Mean 7 and range 2-13 \\
Occupation & Agropastoralist 87.8\% and \\
& pastoralist 12.2\% \\
Land holding size (ha) & Mean 4 with max. of 15 \\
Livestock (TLU) & Mean 10.21 with max. of 57.6 \\
Livestock composition (\%) & Camel (25.3), cattle (45.2), goat (15.3), \\
& sheep (7.4), and donkey (6.8) \\
Religions (\%) & Muslim (50), Wakefeta (28), Christianity \\
& (12.2), and others (9.8) \\
\hline
\end{tabular}


57.6 TLU. Camel, cattle, goat, sheep, and donkey were the major livestock species in the study areas. A considerable proportion of households are managing diverse livestock composition. In this case, the results showed that $45.2 \%, 25.3 \%$, and $15.3 \%$ of the survey households reported owning cattle (4.61 TLU), followed by camels (2.58 TLU) and goats (1.56 TLU), respectively (Table 1).

\section{Dry forest income contribution to household income}

According to the results, the main income sources for the surveyed households in the study area could be categorized under livestock production (34.4\%), farming or crop production (22.0\%), forest products (14.9\%), non-farm (23.7\%), and support from government and non-governmental organizations (Fig. 2a). The income from crops consists of both for own consumption and sale in the year inputs. The average total annual income of sample households was 11,209.7 $\mathrm{ETB}^{2}$, and out of this, $14.9 \%$ was the income from dry forest products which mainly include gum and resin (29.8\%), fodder (20\%), firewood (15.7\%), construction materials (13.9\%), and others (Fig. 2b).

In contrast, according to the respondents' response, cost incurred to satisfy the demand of household food consumption (34\%) and purchase of fodder (22.1\%) for the livestock during the drought season took the lion's share followed by livestock exchange $(10.7 \%)$ and others (33.4\% for cost related with health care, small scale trade, and school fees).

On the other hand, the results indicated that the dry forest contribution was significantly affected by the kebeles. The highest mean annual income from the dry forest (3512.37 \pm 2634.52 ETB) was recorded in the Melka-Guba kebele followed by Bulbul (918.66 \pm 1630.84 ETB) kebele. In contrast, the lowest total annual income (177.5 \pm 556.02 ETB) was recorded in the Boba kebele (Table 2).

The results also indicated that from the major factors which have effects on the total annual income of the sample households, the amount of total annual income was statistically influenced by kebeles, combined effect of sex and educational level, and combined effect of kebeles, sex, and educational level of sample households. And also from the factors which affect the dry forest annual income of sample households, kebele affects the statistical significance at alpha 0.05 significance level as shown in Table 3.

\section{The role of dry forests as coping strategy to climate extreme events}

In order to cope climate change effect, the respondents used various methods, and among these, destocking, off-farm, gum and resin, other forest product, aid, and migration held $82.2 \%, 48.6 \%, 69.8 \%, 81.9 \%, 76.4 \%$, and $84.8 \%$, respectively. Among the methods of coping strategies for the respondents, the dry forest contribution for coping climate change effect with the indication of frequent drought phenomena was high which shows with different indicators from respondents, such as the respondents' trends of livelihood dependency on dry forest strongly increased by $69.4 \%$ and increased by $15.3 \%$ through time. As another indicator, $48.6 \%$ of respondents indicated an increased income generation from dry forest product during drought period and $84.7 \%$ of respondents showed an increased time of participation in the use of dry forest products during drought period.

The study showed that the trends of the coping capacity of sample households were highly destabilized (61\%), destabilized (12.2\%), and improving (26.8\%). Among the factors which influence the trends of coping capacity to drought in the last 30 years for sample households, the sex of the head of the family is statistically significant at alpha 0.05 significance level as shown in Table 4. Immediate action with destocking of livestock was one means of reactive measures by households, and the sample respondents have mainly four choices (none, first, second, third, fourth, fifth, and sixth preference and their weights were $18.3 \%, 33.8 \%$, $31 \%$, and $7 \%$, respectively). Among the major factors which influence for immediate action with the destocking of livestock in order to be drought resilient, the total annual income, family size, livelihood strategy, educational level,

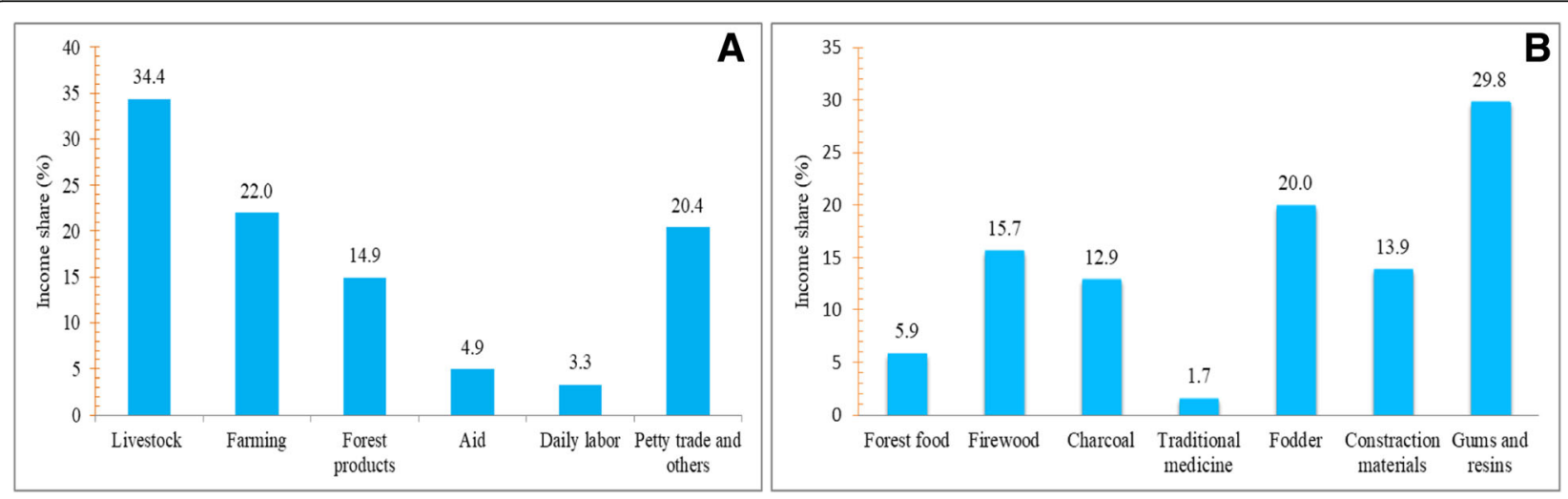

Fig. 2 Households' income share from livelihood strategies (a) and dry forest products (b) 
Table 2 Dry forest income contribution to household income in the selected kebeles

\begin{tabular}{llllll}
\hline Explanatory variables & \multicolumn{2}{l}{ Kebeles (mean \pm standard deviation) } & & Overall $(N=74)$ & \\
\cline { 2 - 4 } & Boba $(N=24)$ & Bulbul $(N=30)$ & Melka-Guba $(N=20)$ & \\
\hline Age & $44.4 \pm 15.50$ & $42.8 \pm 14.91$ & $43.6 \pm 11.19$ & $43.5 \pm 14.04$ \\
Size of family & $6.8 \pm 2.92$ & $6.6 \pm 2.37$ & $7.7 \pm 1.73$ & $6.9 \pm 2.43$ & 0.122 \\
Land size (ha) & $3.9 \pm 2.16$ & $3.75 \pm 2.68$ & $4.32 \pm 2.19$ & $3.94 \pm 2.38$ & 0.326 \\
Dry forest income (ETB/year) (A) & $177.5 \pm 556.02$ & $918.7 \pm 1630.84$ & $3512.4 \pm 2634.52$ & $1379.3 \pm 2183.82$ & $21.688^{*}$ \\
Total income (ETB/year) (B) & $177.5 \pm 556.02$ & $11,982.0 \pm 18,464.99$ & $23,287.9 \pm 17,467.06$ & $11,209.2 \pm 17,180.86$ & $13.250^{*}$ \\
Income (B)-income (A) & $0 \pm 0.0$ & $11,063.4 \pm 17,763.0$ & $19,775.5 \pm 17,282.7$ & $9829.8 \pm 16,204.3$ & $10.399^{*}$ \\
\hline
\end{tabular}

*The significance at $p=0.01$. ETB, Ethiopian birr

kebeles of the study area, sex of sample households are statistically significant at alpha 0.05 significance level as shown Table 4.

The study also found that immediate actions for drought which held with off-farm activities in order to cope with the drought effects in preference of the sample households were none, first, second, third, and fourth and their weights were $51.4 \%, 5.7 \%, 2.9 \%$, and $11.4 \%$, respectively. And factors which influence statistically for the immediate action to drought with off-farm activity were the annual dry forest income and educational level of sample household at alpha 0.05 significance level as shown in Table 4. As like of the above means of immediate actions, sample households also used aid as an immediate action with preference of none, first, second, third, and fourth in the weight of $22.9 \%, 7.1 \%, 12.9 \%, 17.1 \%$, and $12.9 \%$, respectively. In addition to the immediate action for drought with aid, statistically influenced factors to sample households

Table 3 Factors of total annual income and dry forest annual income

\begin{tabular}{lll}
\hline Explanatory variables & Total annual income & Dry forest annual income \\
\hline Corrected Model & 0.003 & 0.007 \\
Intercept & 0.693 & 0.685 \\
Age & 0.768 & 0.807 \\
Family size & 0.547 & 0.189 \\
Livelihood & 0.458 & 0.759 \\
Kebeles & 0.000 & 0.008 \\
Sex & 0.861 & 0.581 \\
Education & 0.156 & 0.358 \\
Livelihood * sex & 0.649 & 0.674 \\
Livelihood * education & 0.746 & 0.368 \\
Kebeles * sex & 0.035 & 0.813 \\
Kebeles * education & 0.085 & 0.375 \\
Sex * education & 0.015 & 0.365 \\
Kebeles * sex * & 0.015 & 0.261 \\
education & &
\end{tabular}

Figures in the table indicate $p$ value $(p=0.01)$ from univariate ANOVA. Asterisk symbol $(*)$ stands for interaction effect of the explanatory variables were the family size and sex of the head of the family at alpha 0.05 significance level as shown in Table 4.

\section{Household livelihood vulnerability and role of dry forests for adaptation \\ Perceived patterns of household livelihood vulnerability}

The majority of the surveyed households, i.e., more than $94 \%$, perceived that the trend of the livelihood vulnerability of the community becomes highly increasing due to extensive and frequent drought impact since three decades ago. On the other hand, $87 \%$ of the surveyed households in the study area responded as highly vulnerable livelihood due to frequent drought occurrences. Only less than 10\% perceived as slight vulnerable this particular year.

More than $75 \%$ of the respondents in the area indicated that the main effect of drought in the area highly reflected on failure on food crops and massive death of livestock species particularly cattle species in recent years. According to results, $61.5 \%$ household heads mentioned that the reason behind the damage on farming and livestock resources in the study area was related with the highly variable rainfall pattern, and $25.6 \%$ perceived that the unstable and movable lifestyle of the pastoralist communities leads to the problems encountered. More than $12 \%$ of the respondents pointed out the communities experiencing an expansion of desertification and depletion of land resources especially on grazing lands.

\section{Effects of drought on households' livelihood vulnerability}

The survey households identified various sources of livelihood vulnerability. These could be categorized into climate change related and ecological or environmental change related. The results indicated that $35.3 \%$ and $29.4 \%$ of the households perceived an increase in temperature and a substantial decrease in annual rainfall, respectively. On the other hand, $17.7 \%$ and $11.8 \%$ of the households perceived increasing variability in distribution and erosive nature of the rainfall, respectively. The rest $6 \%$ of households perceived the death of livestock as a source of vulnerability due to drought. According to key informants and focus discussion, the drought of 2016-2017 could be considered as the most 
Table 4 Factors for immediate action and trends of coping capacity for drought

\begin{tabular}{lll}
\hline Explanatory variables & Total annual income & Dry forest annual income \\
\hline Corrected model & 0.003 & 0.007 \\
Intercept & 0.693 & 0.685 \\
Age & 0.768 & 0.807 \\
Number of family & 0.547 & 0.189 \\
Livelihood & 0.458 & 0.759 \\
Kebeles & 0.000 & 0.008 \\
Sex & 0.861 & 0.581 \\
Education & 0.156 & 0.358 \\
Livelihood * sex & 0.649 & 0.674 \\
Livelihood * education & 0.746 & 0.368 \\
Kebeles * sex & 0.035 & 0.813 \\
Kebeles * education & 0.085 & 0.375 \\
Sex * education & 0.015 & 0.365 \\
Kebeles * sex * & 0.015 & 0.261 \\
education & & \\
\hline
\end{tabular}

Figures in the table indicate $p$ value $(p=0.01)$ from univariate ANOVA. Asterik symbol (*) stands for interaction effect of the explanatory variables

severe ever that devastated their livestock and triggered crop failure in the region as a whole. Moreover, overexploitation of the resources, deforestation, and rangeland degradation lead to social stability interruption and institutional weakness.

In this study, despite the slight variations between localities, generally, respondents were able to categorize major livelihood strategies into different vulnerability scales, ranging from less to high vulnerability. According to Worku (2015), the categorization was based on their accumulated knowledge on the exposure of a particular livelihood strategy to drought risks as well as its adaptive capacity. A particular livelihood strategy was said to be "highly vulnerable" when it has already reached its threshold, and hence, further exposure such as extended drought might lead to its total abandonment. "Moderate vulnerability" refers to a situation where the livelihood strategy seems to be resilient despite its exposure to risk and shocks. A livelihood strategy is referred to as "less vulnerable" when it is less dependent on natural resources, and hence, its relative exposure to ecological stressors is less.
Accordingly, the trend of the households' livelihood vulnerability has increased significantly due to climate-related hazards, for instance, drought events. Majorities of the surveyed households, 94.6\%, argued that their livelihood vulnerability is highly increasing, and $4.1 \%$ respondents perceived increasing vulnerability while the rest $1.4 \%$ perceived no visible vulnerability change in the past 30 years. Moreover, in this particular year, $87.8 \%$ of the respondents perceived that their livelihood becomes highly vulnerable due to frequent drought events and $10.8 \%$ of the surveyed households argued that their livelihood has become vulnerable to drought recently. Others, $1.4 \%$ of the respondents perceived no visible vulnerability change in the study area.

Results showed that the loss of massive livestock population and failure in crop production were main factors which affected the livelihood coping capacity to drought and lead the surveyed households more susceptible to climate-related risks, drought in particular. For instance, $76.7 \%$ of the respondents indicated that the combined effect of the livestock death and decline in farming activities in the surveyed households could trigger the susceptibility to drought. On the other hand, $16.4 \%$ of the respondent only blamed the death of livestock, in particular. The rest $6.8 \%$ of the households argued on other factors.

On the other hand, the effect of drought has also been related with the annual income of the households. Almost all respondents perceived that annual income generated from their livelihood strategies, especially from livestock and crop production, substantially reduced due to the prevailing drought effects in the area (Table 5).

Similarly, the trend of households' coping capacity has destabilized due to drought since three decades ago. Majorities of the respondents, $62.8 \%$, perceived that their coping capacity has been "highly destabilized" due to frequent drought events and $11.6 \%$ rated as "destabilized." In contrast, $25.6 \%$ of the respondents perceived their coping capacity to drought as "improving" in the past 30 years. In this regard, results indicated that 2.12 TLU of camel and 11.86 TLU of cattle stock have been lost per household in 2017, respectively (Table 6).

The severity of the drought has also manifested in terms of the effect on social networking. For instance, $66.7 \%$ and $33.3 \%$ of the respondents criticized that drought has become a source of conflict due to interest and breaking on

Table 5 Summary of households' response on effects of drought on livelihood strategies

\begin{tabular}{llll}
\hline Livelihood & \multicolumn{2}{l}{ Respondents' responses on trend in annual income $(N=74(\%))$} & No change \\
\cline { 2 - 4 } strategies & Increasing & Decreasing & 0 \\
\hline Livestock & 0 & 100 & 1.9 \\
Crop farming & 0 & 98.1 & 10.6 \\
Forest products & 10.6 & 78.8 & 26.6 \\
Off-farm activities & 17.2 & 56.3 & 2 \\
\hline
\end{tabular}


Table 6 Summary of mean livestock population lost per household due to drought

\begin{tabular}{lll}
\hline Livestock species & \multicolumn{2}{l}{ Livestock population lost per household in 2017 } \\
\cline { 2 - 3 } & Mean (TLU \pm standard deviation) & Maximum \\
\hline Camel & $2.12 \pm 3.22$ & 15 \\
Cattle & $11.86 \pm 12.38$ & 89 \\
Goats & $1.26 \pm 1.33$ & 50 \\
Sheep & $0.84 \pm 0.86$ & 38 \\
Total & 16.08 & 192 \\
\hline
\end{tabular}

social stability. Moreover, $97.3 \%$ of respondents perceived that the trend and status of the desertification have been highly expanding in the past three decades and become the main threat for communities' livelihood.

\section{Role of dry forests for households' adaptation}

Rather than other livelihood strategies, results indicated an increasing trend of household livelihood dependency on the dry forests since three decades ago. Majorities of the surveyed households, $67.6 \%$, perceived "strongly increasing" and $14.9 \%$ perceived "increasing" trend of livelihood dependency on dry forests. In contrast, $5.4 \%$ of respondents responded "decreasing" trend of dependency on forests while only $9.5 \%$ of respondents felt "no change" on their livelihoods. This could be due to the increasing trend of the households in the dry forests during drought periods. Accordingly, more than $83 \%$ of the respondents indicated increment in terms of the level of engagement, participation of family members, and time of participation in the dry forests. Similarly, $48.6 \%$ of the households argued that the income generated from dry forests increased substantially (Table 7).

Regarding the livelihood strategies, livestock and crop production could be considered as highly vulnerable, i.e., $52.8 \%$ and $47.2 \%$, respectively, to climate-related risks in contrary to dry forest products and off-farm activities, i.e., $4.2 \%$ and $2.8 \%$, respectively (Table 8 ). Moreover, $95.9 \%$ and 93.1\% of respondents perceived that dry forest products are less vulnerable.

Surveyed households identified the most resilient livelihood strategies against both climate- and environment-related risks. Majorities of respondents, $39.6 \%$, perceived that off-farm activities $(35.8 \%$ for petty trade and $3.8 \%$ for daily labor) become more resilient during drought periods. Key informant interviews and focus group discussion results indicated that off-farm activities were climate-independent and simple to exchange and generate daily income for the households.

On the other hand, $35.8 \%$ of the households responded that livestock production, particularly camels and goats, makes the livelihood strategies resilient (Fig. 3), and hence, key informants also agreed upon the shift in the diversity of livestock species towards camels and goat that mainly depend on browsing tree leaves during drought seasons. Similarly, 9.4\% of the respondents argued that dry forest products $(7.5 \%$ for gums and resins; $1.9 \%$ for charcoal sold) become resilient in drought and the rest $13.2 \%$ of households considered the combination of petty trade and forest products as resilience livelihood strategies in the study area.

\section{Status and traditional dry forests management systems}

For the past 30 years, results indicated that status of the dry forests is shrinking in significant rates. Majorities of the respondents (89.8\%) perceived the dry forest as highly declining and the rest, only $10.2 \%$, of respondents perceived moderately decreasing in the past 30 years. Moreover, the status of the high-value woody species found in the dry forests showed notable shrinkage in terms of forest cover, species abundance, and regeneration in the area. For instance, more than $96.6 \%$ of the respondents perceived a notable decrease in high-value species in the dry forests while the remaining $1.7 \%$ of respondents perceived either increase or no significant change in species composition and density in the dry forests. On the other hand, major driving factors that triggered the change in forest cover, species diversity, and regeneration include pressure due to drought and population increments, deforestation and degradation, overexploitation of the forest resources, and decrease in annual rainfall amount, and uneven distribution of rainfall nature in the area (Fig. 4).

The results also indicated that the main purposes in which the respondents manage the dry forests include as rangeland (82.5\%), as source of food (11.1\%), as source of non-timber forest products (1.6\%), and as means of combating desertification (4.8\%).

Table 7 Trend of engagement in the dry forests during drought periods

\begin{tabular}{llll}
\hline Indicating parameters & \multicolumn{2}{l}{ Respondents' response on the trend of engagement in the dry forests $(N=74(\%))$} \\
\cline { 2 - 4 } & Increasing & Decreasing & No change \\
\hline Level of engagement in dry forests & 84.7 & 5.6 & 9.7 \\
Number of families participating in dry forests & 83.3 & 4.2 & 12.5 \\
Time of participation in dry forests & 84.7 & 4.2 & 11.1 \\
Income generated from dry forest products & 48.6 & 27.1 & 24.3 \\
\hline
\end{tabular}


Table 8 Respondents' response of on the vulnerability level of different livelihood strategies

\begin{tabular}{llll}
\hline \multirow{2}{*}{ Livelihood strategies } & \multicolumn{2}{l}{ Respondents' response of on the vulnerability level $(N=74(\%))$} & Less vulnerable \\
\cline { 2 - 4 } & Highly vulnerable & Moderately vulnerable & 2.8 \\
\hline Livestock & 52.8 & 44.4 & 9.7 \\
Crop production & 47.2 & 43.1 & 95.9 \\
Gum and resin & 2.8 & 1.4 & 93.1 \\
Other forest products & 1.4 & 5.6 & 93.1 \\
Off-farm activity & 2.8 & 4.2 & 9 \\
\hline
\end{tabular}

\section{Discussion}

\section{Dry forests income contribution to household income}

The main income sources for the surveyed households were livestock production, farming, forest products such as gum and resin collection, charcoal making, firewood selling, and non-farm activities such as petty trade, labor, and support from government and non-governmental organizations operating in the study area. The income from livestock production consists of milk offtake for own consumption and sales, livestock sales, and slaughter for own consumption. The income from crops consists of both for own consumption and sale in the year inputs. From the total annual income of sample households, $14.9 \%$ was income from dry forest products such as gum and resin, firewood, charcoal, and others. According to Frederik et al. (2015), the mean annual forest income from sub-Saharan Africa was $\$ 158$ and forest cash income was $\$ 82$, and according to Busha et al. (2015), the mean annual income from forest product was $1740 \mathrm{ETB}$, and from the forest annual income, fuelwood held $57.8 \%$, gum and resin $39.9 \%$, and other forest products $2.3 \%$ in Ethiopia Northwestern and Southern lowlands with districts of Asgede-Tsimbla in Tigray region, Quara in Amhara region, and Yabelo in Oromia region. In addition, according to Dagm et al. (2016), the mean annual income of Southeastern Ethiopia in the district of Hammer was 12,450 ETB and major income sources were livestock (29.7\%), forest (21.4\%), and crop
(15.7\%) from the mean annual income. This show that the dry forest ecosystem is highly contributing to the household livelihoods.

In the other hand, the results indicated that the dry forest contribution was significantly affected by the kebeles. The highest mean annual income was recorded from the dry forest in the Melka-Guba kebele, and the lowest total annual income was recorded in the Boba kebele. The results also indicated that the amount of total annual income was statistically influenced by kebeles, combined effect of sex and educational level, and combined effect of kebeles, sex, and educational level of the sample households. Other studies also indicate that some factors influence forest income, among them are household size, non-forest income, distance from forest, and cooperative members (Charles et al. 2010; Busha et al. 2015), and according to Dagm et al. (2016), major statistically significant factors for dry forest income were site, sex, household size, land size, access to extension, and farm activity. Moreover, even without including their monetary values as range of resources and their environmental services, forests offered one of the most diverse incomes in relation to the rest of the main income strategies. In addition to managing forests as range of sources, the study households collected different types of forest products, such as gum and resins, firewood and charcoal, wood for construction and farm tools, medicinal

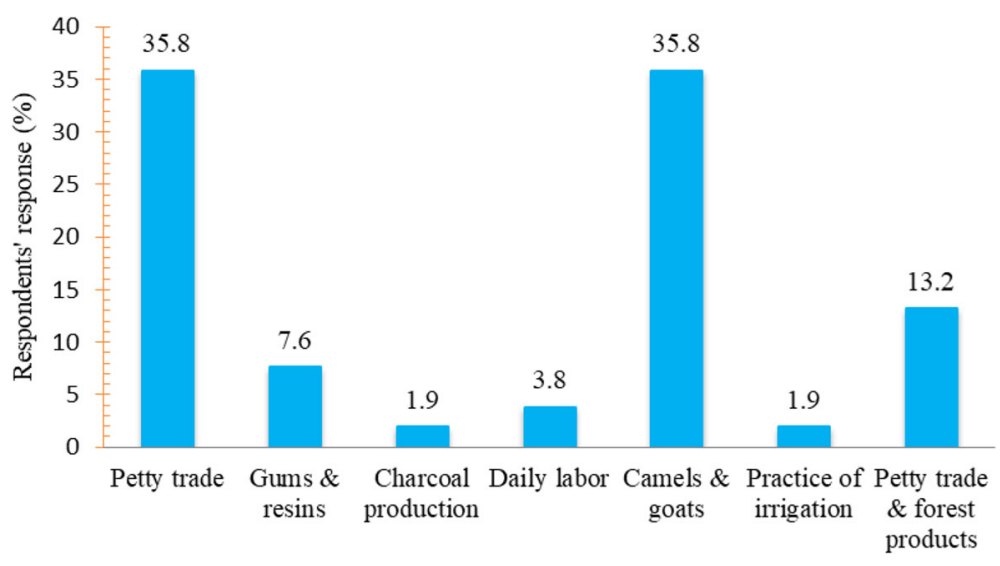

Fig. 3 Respondents' response on resilient livelihood strategies during drought periods 


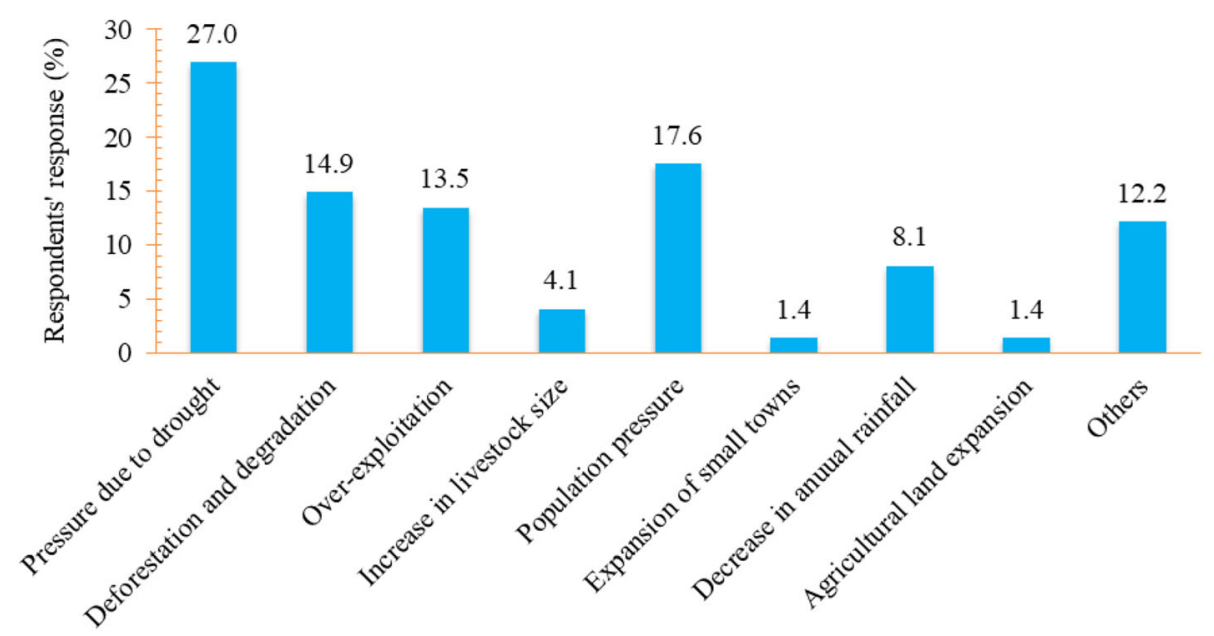

Fig. 4 Driving factors that triggered change in species diversity

plants, and forest food, both for subsistence and cash income (Worku 2015).

\section{The role of dry forests as coping strategy to climate extreme events}

In order to cope climate change effect, the respondents used various methods, among these are destocking, off-farm, gum and resin, other forest product, aid, migration, and others. According to Temesgen et al. (2010), the households in the Nile Basin of Ethiopia used nothing (51.3\%), sold livestock (26\%), and borrowed from relatives (10\%) for coping climate extreme events. In other study, according to Andrew et al. (2007), the sample households of Kenya in the districts of Turkana, Marsabit, Malindi, and Garissa used food aid, reliance on friends and relatives, sales of asset-diversifying income source, casual labor, and migration with their preference of first, second, third, fourth, fifth, and sixth accordingly for their coping strategies of climate extreme events.

As means of immediate actions, the sample households also used aid as of immediate action with the preference of none, first, second, third, and fourth in the weight of $22.9 \%, 7.1 \%, 12.9 \%, 17.1 \%$, and $12.9 \%$, respectively. In addition to the immediate action for drought with aid, statistically influenced factors to the sample households were the family size and sex of the head of the family at alpha 0.05 significant levels as shown in Table 3. According to Temesgen et al. (2010), factors which affect the statistical significance of choosing different coping strategies were educational level, sex of the head of the family, farm income, livestock ownership, access to extension service positively influenced, non-farm income, farm size, agroecology with kola, and precipitation negatively influenced for the use of one or combination of the coping strategies of farmers in the Nile Basin of Ethiopia.

\section{Household livelihood vulnerability and role of dry forests} for adaptation

Results showed that the loss of massive livestock population and failure in crop production were main factors which affected the livelihood coping capacity to drought and leads the surveyed households more susceptible to climate-related risks, drought in particular. For instance, majorities of the respondents indicated that the combined effect of the livestock death and decline in farming activities in the surveyed households could trigger the susceptibility to drought. Furthermore, key informants and focus group discussion indicated that the effect of drought manifested on the decline in crop production in terms of quality and quantity, less availability of fodder, low productivity, and death of livestock that could be factors affecting the household vulnerability. A similar study done by Meseret (2013) also indicated that majority $(88.5 \%)$ of the respondents indicated that the contribution of livestock income to the household total income is also declining over time while only $10 \%$ of the respondents had a contrary feeling that the contribution from livestock showed an increasing trend. Those who claimed a decreasing livestock trend related the change to climate change effect that is causing the increasing incidence of livestock diseases, increased weeds, and invasive species infestation, hence affecting feed and fodder availability that negatively affected the livestock productivity. They also associated climate change impact to the reduced availability of water.

A study conducted in the Borana Zone by Kejela et al. (2007) also corroborates with the findings of this study. The study showed a decline in livestock production and productivity over the past three decades in Borana which is affected by the increasing frequency and intensity of drought. A similar study by Dewit and Stankiewicz (2006) and IISD (2007) cited by Meseret (2013) also indicates that 
the disruption of sufficient supply of feed and water systems as the result of invasive plant encroachment is impacting the development in general and livelihoods of pastoralists and agropastoralists in particular, and these problems are expected to exacerbate under climate change-related challenges.

In other studies, droughts have been anticipated to occur 5 to 6 years in the Borena rangeland (Desta and Coppock 2002), but both their frequency and severity may be rising. Droughts deplete cattle population through heightening mortality and forced offtake. A warning and drying trend in climate negatively affects the rangeland productivity by lowering the quantity and nutritional quality of forages besides causing water scarcity (Thornton et al. 2009; Nardone et al. 2010). Climate change has already brought about observable changes in East Africa, such as declines in rainfall, changing rainfall seasonality, and increasing frequency of droughts (Williams and Funk 2010; Williams and Funk 2011). Evidence for declining rainfall has also been documented for Ethiopia (Cheung et al. 2008; Viste et al. 2013) with a significant decrease in the long rains in the southern part of the country.

On the other hand, the results indicated an increasing trend of household livelihood dependency on the dry forests since three decades ago. Majorities of the surveyed households perceived a "strongly increasing" trend of livelihood dependency on dry forests. For instance, the majorities of households responded that livestock production, particularly camels and goats, makes the livelihood strategies resilient, and hence, the key informants also agreed upon the shift in the diversity of livestock species towards camels and goat that mainly depend on browsing tree leaves during drought seasons. Climate change, especially the increasing frequency and intensity of droughts, accentuates the impact of these stressors, undermining the traditional coping strategies and deepening the vulnerability of the pastoralists. Cattle are the livestock species most susceptible to water and feed shortages engendered by climate change (Seo et al. 2010). Moreover, the study conducted by Meseret (2013) indicated that Borena herders who have historically been cattle pastoralists are reportedly responding to environmental changes by adjusting their herd composition, i.e., keeping more tolerant species such as camels and goats (Zander 2011). In other words, the shift is due to the fact that cattle and sheep are found more vulnerable to drought and forage deficit following the continuous invasion of rangelands with more invasive woody species. Relatively, camels are better dry season tolerant, offer milk for sale even when cows are not milking, and has high price when sold. Like camels, goats are also better dry season tolerant and offer milk for children and they are browsers; hence, forage deficit is not a problem. This result is supported by Solomon (2000) and Meseret (2013) that showed Borana society increases the tendency to rearing camel and goat which have a higher resistance to drought than other livestock species and small ruminant also appears tolerant to drought because of their low nutritional requirement and feeding behavior.

\section{Status and traditional dry forests management systems}

For the past 30 years, results indicated that the status of the dry forests is shrinking in significant rate. Majorities of the respondents perceived the dry forest is highly declining, and the major driving factors that triggered the change in forest cover and species diversity and regeneration include pressure due to drought and population increments, deforestation and degradation, and overexploitation of the forest resources. Climate change could be the biggest cause of increased extinction rates in many regions, especially in the tropics (Thomas et al. 2004; Fischlin et al. 2007), and land-use change, such as deforestation, is also an important and synergistic driver (cf. Sala et al. 2000, for a recent comprehensive review see Fischlin et al. 2007). Deforestation and degradation through infrastructure development, plus non-sustainable practices, result in fragmented forests and biomass losses at large spatial scales, which could be greater in $\mathrm{CO}_{2}$-induced climate change (Zhao et al. 2005). The results are again impoverished forests with reduced productivity.

\section{Conclusion}

Findings indicated that frequent and persistent drought in recent years has a negative effect on the availability of food and on the nutritional status of people through the loss of assets (especially livestock and crops) and dry forest products. The trends of livelihood dependency on dry forest of the respondents were strongly increasing indicating that dry forest income is now becoming essential with the occurrence of drought in the area. Results indicated that dry forests are playing a crucial role in improving the adaptive capacity of the drought-prone communities through enhancing their socioeconomic and ecological resilience. And also, nearby dry forest ecosystem has its own contribution to the total annual income of households. In the study area, the households used various methods for coping strategies for climate extreme events, among these were destocking of animals; off-farm activities; gum, resin, and other forest products; aid; and migration.

Strengthening of the traditional ecological knowledge to promote local dry forest management is crucial particularly when applied to the rehabilitation, restoration, and adaptive management of forests, for instance, promoting the "Kalo" system and raising the communities' awareness to reduce the livestock, i.e., destocking and diversification. It is important to improve the management of dry forests for livelihood 
enhancement, while also securing their long-term ecological functions. These could be achieved via promoting their integration into the national, regional, and local development planning. And also, needs of strengthening ecosystem services of dry forest for communities include income source with appropriate management plan of dry forest ecosystem to increase the coping capacity of the local community for climate extreme events like drought.

\section{Endnotes}

${ }^{1} \mathrm{TLU}$ is tropical livestock unit as defined in Storck et al. (1991).

${ }^{2}$ ETB stands for Ethiopia birr equivalent to 0.035 USD $(15 / 01 / 2019)$.

\begin{abstract}
Abbreviations
CIFOR: Center for International Forestry Research; CSA: Central Statistical Agency; ECA: Economic Commission for Africa; EEFRl: Ethiopian Environment and Forest Research Institute; ETB: Ethiopian birr; FAO: Food and Agricultural Organization; IPCC: Intergovernmental Panel for Climate Change; m.a.s.l: Meter above sea level; NAPA: National Adaptation Programme of Action of Ethiopia; NTFPs: Non-timber forest products; SPSS: Statistical Package for Social Scientists; TLU: Tropical livestock unit
\end{abstract}

\section{Acknowledgements}

The financial support from Ethiopian Environment and Forest Research Institute (EEFRI) is highly acknowledged. We are grateful to all staff colleagues and Guji zone, Liben Woreda Environment and Forest Protection office members who participated through data collection, analysis, and final edition of this manuscript. Last, but not the least, my special thanks go to key informants and heads of surveyed households for their kind respect and support while collecting data.

\section{Funding}

The study was supported by Ethiopian Environment and Forest Research Institute (EEFRI) through provision of finance.

\section{Availability of data and materials}

Not applicable.

\section{Authors' contributions}

All authors played a crucial role during the study period. The corresponding author, WA wrote the manuscript and collected and performed the statistical analysis. GS carried out the regression analysis and drafted the manuscript. AW and ZM participated in the design of the study and examined the manuscript. MT conceived of the study, and participated in its design and coordination, and helped to draft the manuscript. All authors read and approved the final manuscript.

\section{Ethics approval and consent to participate}

Not applicable.

\section{Consent for publication}

Not applicable.

\section{Competing interests}

The authors declare that they have no competing interests.

\section{Publisher's Note}

Springer Nature remains neutral with regard to jurisdictional claims in published maps and institutional affiliations.

\section{Author details}

Hawassa Environment and Forest Research Center, P.O.Box: 1832, Hawassa, Ethiopia. ${ }^{2}$ Ethiopian Environment and Forest Research Institute, P.O.Box:

24536 (Code 1000), Addis Ababa, Ethiopia.

Received: 18 November 2018 Accepted: 7 March 2019

Published online: 03 April 2019

\section{References}

Andrew M, Robert O, Jeannette V, Juliet K, Denis O, Annita T. Kenya adaptation to climate change in the arid lands: anticipating, adapting to and coping with climate risks in Kenya-operational recommendations for KACCAL. ILRI Research Report 18. Nairobi: International Livestock Research Institute; 2007.

Bekele A, Amsalu A. Effects of drought on pastoral household in Fentale Woreda of Oromia Regional State. J Environ Issues Agri Dev Countries. 2012;4:1-19.

Busha T, Habtemariam K, Zerihun M, Christine P. Contribution of dry forest products to household income and determinants of forest income levels in the northwestern and southern lowlands of Ethiopia; 2015.

Campbell BM, Jeffrey S, Kozanayi W, Luckert M, Mutamba M, Zindi C. House-hold livelihoods in semi-arid regions, options and constraints. Indonesia: CIFOR; 2002.

Cavendish W. How do forests support, insure and improve the livelihoods of the rural poor? A research note. Bogor: CIFOR; 2003.

Charles B, Samuel M, Madeleen H. Contribution of dry forests to rural livelihoods and the national economy in Zambia; 2010.

Cheung WH, Senay GB, Singh A. Trends and spatial distribution of annual and seasonal rainfall in Ethiopia. Int J Climatol. 2008;28:1723-34.

CIFOR, 2010. The poverty environment network (PEN) prototype questionnaire, https://www.cifor.org/pen/the-pen-prototype-questionnaire/ (15/6/2013).

CIFOR (Center for International Forestry Research). In: Sunderland T, Ndoye O, editors. Forest products, livelihood and conservation, case study of NTFPs systems. vol 2-Africa. Bogor: CIFOR; 2005.

Colding J, Folke C, Thomas E. Social institutions in ecosystem management and biodiversity conservation. Trop Ecol. 2003:44:25-41.

Coppock DL. The Borana Plateau of Southern Ethiopia: synthesis of pastoral research, development and change, 1980-1991. Addis Ababa: ILCA; 1994.

Creswell W. Qualitative, quantitative and mixed methods approach. New Delhi: SAGE Publications; 2009.

CSA (Central statistical Agency). Summary and statistical report of the 2007 population and housing census. Addis Ababa: Federal Democratic Republic of Ethiopia: Population Census Commission; 2007.

Dagm, F. Wubalem, T. Abdella, G. 2016. Economic contribution to local livelihoods and households dependency on dry land forest products in Hammer District, Southeastern Ethiopia. Hindawi Publishing Corporation International Journal of Forestry Research Article ID 5474680, 11 pages. https://doi.org/10.1155/2016/5474680

Davies J, Poulsen L, Schulte HB, Mackinnon K, Crawhall N, Henwood HW, Dudley N, Smith J, Gudka M. Conserving dryland biodiversity; 2012.

Desta S, Coppock DL. Cattle population dynamics in the southern Ethiopian rangelands, 1980-1997. J Range Manag. 2002;55:439-51.

Dewit M, Stankiewicz J. Changes in surface water supply across Africa with predicted climate change. Science. 2006;311:17-21.

ECA (Economic Commission for Africa). Africa review report on drought and desertification. Fifth meeting of the Africa Committee on Sustainable Development (ACSD-5), Regional implementation meeting (RIM) for CSD-16. Addis Ababa: ECA; 2007.

FAO. Review of evidence on drylands pastoral systems and climate changeimplications and opportunities for mitigation and adaptation. In: Neely C, Bunning S, Wilkes A, editors. Land and water discussion paper, 8. Rome: FAO; 2009.

FAO. Guidelines on sustainable forest management in drylands of sub-Saharan Africa. Arid zone forests and forestry, working paper no. 1. Rome: FAO; 2010.

Fekadu B. Property rights conflict, customary institutions and the state: the case of agro-pastoralists in Mieso district, Eastern Ethiopia. J Mod Afr Stud. 2009;47:213-39.

Fekadu B. Locating the adverse effects of rangeland enclosure among herders in eastern Ethiopia. Land Use Policy. 2010;27:480-8.

Fekadu B. Multiple tournaments and sustained defection: why do negotiations fail to secure resource access between pastoral and agro-pastoral groups in Ethiopia? J Socio-Econ. 2013;42:79-87.

Fischlin A, Midgley GF, Price JT, Leemans R, Gopal B, Turley C, Rounsevell MDA, Dube OP, Tarazona J, Velichko AA. Ecosystems, their properties, goods, and services. In: Parry ML, Canziani OF, Palutikof JP, van der Linden PJ, Hanson CE. (eds.). Climate change 2007: impacts, adaptation and vulnerability. 
Contribution of Working Group II to the Fourth Assessment Report of the Intergovernmental Panel on Climate Change. Cambridge: Cambridge University Press; 2007. p. 211-272.

Frederik N, Sven W, Arild A, Jan B. Responses to weather and climate; a crosssection analysis of rural incomes: World Bank group; 2015.

Haugen T. Woody vegetation of Borana, South Ethiopia. A study on the main vegetation types of the Borana. SINET: Eth J Sci. 1992;15(2):117-30.

Homann S. Towards endogenous livestock development: Borana pastoralists' responses to environmental and institutional changes. Hum Ecol. 2008;36:503-20.

IISD (International Institute for Sustainable Development). Community based adaptation to climate change bulletin. A summary of the second international workshop on community-based adaptation to climate change Vol.135. Dhaka: IISD Reporting Services; 2007.

IPCC. Africa: climate change, impacts, adaptation and vulnerability. In: Parry ML, Canziani OF, Palutikof JP, van der Linden PJ, editors. Contribution of working group II to the fourth assessment report of the IPCC on climate change. UK: Cambridge University Press; 2007. p. 433-67.

Kassahun A, Snyman HA, Smit GN. Impact of rangeland degradation on the pastoral production systems, livelihoods and perceptions of the Somali pastoralists in eastern Ethiopia. JArid Environ. 2008;72:1265-81.

Kejela G, Bezabih E, Waktole T. Livelihood diversification in Borana pastoral communities of Ethiopia-prospects and challenges, research article, WABEKBON consultant; 2007.

Lemenih M, Kassa H. Opportunities and challenges for sustainable production and marketing of gums and resins in Ethiopia. Bogor: CIFOR; 2011.

Meseret K. Perception on climate change; adaptation strategies and their determinants in Borena, Oromiya national regional state of Ethiopia. Master's thesis: University of Hawassa, Wondo Genet College of Forestry and Natural Resources, Wondo Genet, Ethiopia (Unpublished); 2013.

NAPA. Ethiopian climate change national adaptation programme of action. Addis Ababa: Governmant of Federal Democratic Republic of Ethiopia (FDRE); 2007.

Nardone A, Ronchi B, Lacetera N, Ranieri MS, Bernabucci U. Effects of climate changes on animal production and sustainability of livestock systems. Livest Sci. 2010;130:57-69.

Robledo C, Clot N, Hammill A, Riché B. The role of forest ecosystems in community-based coping strategies to climate hazards: three examples from rural areas in Africa. Forest Policy Econ. 2012;24:20-8.

Sala OE, Chapin FS III, Armesto JJ, Berlow R, Bloomfield J, Dirzo R, Huber-Sanwald E, Huenneke LF, Jackson RB, Kinzig A, Leemans R, Lodge D, Mooney HA, Oesterheld M, Poff NL, Sykes MT, Walker BH, Walker M, Wall DH. Global biodiversity scenarios for the year 2100. Science. 2000;287:1770-4.

Seo SN, McCarl BA, Mendelsohn R. From beef cattle to sheep under global warming? An analysis of adaptation by livestock species choice in South America. Ecol Econ. 2010;69:2486-94.

Solomon D. Pastoralism and natural resource management. The case of the pastoral Borana in southern Ethiopia, Proceedings of the Eighth Annual Conference of Ethiopian Society of Animal Production. Addis Ababa: Ethiopian Society of Animal Production (ESAP); 2000. p. 17-27.

Storck H, Emana B, Adnew B, Borowiccki A, Woldehawariat S. Farming systems and resource economics in the tropics: farming system and farm management practices of small holders in the Hararghe Highland, vol. II. Germany: Wissenschaftsverlag Vauk, Kiel; 1991.

Temesgen T, Claudia R, Rashid M. Factors affecting the choices of coping strategies for climate extremes: the case of farmers in the Nile Basin of Ethiopia; 2010.

Thomas CB, Cameron A, Green RE, Bakkenes M, Beaumont L, Collingham YC, BFN E, Ferreira de Siqueira M, Grainger A, Hannah L, Hughes L, Huntley B, van Jaarsveld AS, Midgley GF, Miles L, MA OH, Peterson AT, Phillips OL, Williams SE. Extinction risk from climate change. Nature. 2004;427(8):145-8.

Thornton PK, van de Steeg J, Notenbaert A, Herrero M. The impacts of climate change on livestock and livestock systems in developing countries: a review of what we know and what we need to know. Agric Syst. 2009;101:113-27.

Viste E, Korecha D, Sorteberg A. Recent drought and precipitation tendencies in Ethiopia. Theor Appl Climatol. 2013;112:535-51.

Williams AP, Funk C. A westward extension of the tropical Pacific warm pool leads to march through June drying in Kenya and Ethiopia: U.S. Geological Survey Open-File Report; 2010.

Williams AP, Funk C. A westward extension of the warm pool leads to a westward extension of the Walker circulation, drying eastern Africa. Clim Dyn. 2011;37:2417-35

Worku A. Management of dry forests for socio-ecological resilience of pastoral and agro-pastoral communities in the dry zone of Ethiopia. Ph.D.
Dissertation. Germany: Technische Universität Dresden, Institute of International Forestry and Forest Products; 2015.

Worku A, Lemenih M, Fetene M, Teketay D. Socio-economic importance of gum and resin resources in the dry woodlands of Borana, southern Ethiopia. Forests, Trees, Livelihoods. 2011;20:137-56.

Zander KK Attitudes of livestock keepers to breeding strategies: threats and opportunities for on-farm conservation of the Borana cattle breed. J Agric Sci. 2011:3:3-12.

Zenteno M, Zuidema PA, Jong W, Boot René GA. Livelihood strategies and forest dependence: new insights from Bolivian forest communities. Forest Policy Econ. 2012;26:12-21.

Zhao YX, Wang CY, Wang SL, Tibig L. Impacts of present and future climate variability on agriculture and forestry in the humid and sub-humid tropics. Climate Change. 2005;70(1-2):73-116.
Ready to submit your research? Choose BMC and benefit from:

- fast, convenient online submission

- thorough peer review by experienced researchers in your field

- rapid publication on acceptance

- support for research data, including large and complex data types

- gold Open Access which fosters wider collaboration and increased citations

- maximum visibility for your research: over $100 \mathrm{M}$ website views per year

At BMC, research is always in progress.

Learn more biomedcentral.com/submissions 